\title{
THE INFLUENCE OF EMOTIONAL AFFINITY TOWARD NATURE AND INSTITUTIONAL SUPPORT ON ENVIRONMENTAL RESPONSIBILITY BEHAVIOUR: A RELIABILITY TEST
}

\author{
Logeswari Uthama puthran ${ }^{1}$ \\ ${ }^{1} \mathrm{PhD}$ Scholar, \\ School of Business Management, \\ Universiti Utara Malaysia, \\ Kedah, \\ Malaysia
}

\author{
Fais Ahmad ${ }^{2}$ \\ ${ }^{2}$ Associate Professor, \\ School of Business Management, \\ Universiti Utara Malaysia, \\ Kedah, \\ Malaysia
}

\author{
Hazlinda Hassan ${ }^{3}$ \\ ${ }^{3}$ Senior Lecturer, \\ School of Business Management, \\ Universiti Utara Malaysia, \\ Kedah, \\ Malaysia
}

Article DOI: https://doi.org/10.36713/epra3991

\begin{abstract}
Over the last few decades, environmental issues such as global warming, acid rain, air pollution, urban sprawl, waste disposal, ozone layer depletion, water pollution and climate change have facing concern among prominent world organisational annual meeting and occasions. Almost media covers the environmental and sustainability issues in their daily publications. Malaysia as a developing country starving to survive with annual climate change issues such as flash floods, haze, water and air pollution and increasing seasonal sicknesses. In conjunction, government, policymakers, learning institutions, and Non-Government Organisations (NGOs) play their role in educating people to attain sustainability lifestyle. Specifically, institution leaders as a change agent encourage adapting environmental behaviour to enhancing environmental attitude and behaviour among their stakeholders. Therefore, the purpose of this study is to test the reliability of environmental responsive behaviour, specifically among school leaders in Malaysia. For this study, 503 samples were used to test reliability. The findings indicated that all examined variables consistently reflect the construct it is measuring. Hence, adapted measurement items are reliable to use in future studies.
\end{abstract}

\section{INTRODUCTION}

Generally, emerging global environmental challenges threatens human health, physical security, material needs and social cohesion. It has proven by increasingly intense and frequent storms, rising sea level, extensive flooding, drought, acid rain, deforestation, increase of the carbon dioxide and greenhouse gases, land degradation, and overconsumption of energy (Alberti, 2015; Enger \& Smith, 2015). Consequently, ecological impacts in Malaysia alarming for implementation of policies, procedures and guidelines integrated with environmental sustainability. Cameron Highland mud floods 2013, Hulu Langat landslide 2011, tsunami 2004 and Highland Tower 1993 are some of the notable environmental disasters that have been occurred in Malaysia (Abdul Rahman, 2014). Furthermore, environmental degradation and local socio-economic revolution caused the Malaysia government to expend RM2,236.7 million to environmental protection expenditure for 2013.

Although there are numerous regulations available, daily's update shows that environmental offences are frequent outbreaks. Importantly, the 
Environmental Quality Act 1974 implemented to attain sustainability by the striking balance between environmental preservation and economic expansion (Mustafa, 2011; Nor, Bahari, Adnan, Kamal, \& Ali, 2016). Apart from that, other environmental law and policies such as the Natural Resources and Environment Ordinance 1997, the Protection of Wildlife Act 1972 Act 76, the Fisheries Act 1985 Act 317, the National Forestry Act 1984, the National Parks Act 1980, the Town and Country planning Act 1976 (Mohammad, 2011) are prominent regulation to tract those who are jeopardise wellbeing of nature. On the other hand, International Organization Standardization certification for environmental (ISO 14000) is an excellent tool for an organisation to improve sustainability attributes in their principal activity. ISO 14000 accreditation is catering a guideline for organisations to improve their environmental management efforts (Mustafa, 2011).

\section{LITERATURE REVIEW}

Environmental disasters depicted as major threaten for human life. All the above efforts specifically government initiatives become baseless without transformation of human behaviour to actual environmental sustainability behaviour. Importantly, sustainability is not the only responsibility of the government. It is impossible for the government policy to success without the dedication and commitment from its stakeholders such as implementers. Notably, no real reform can occur without education immersion (Hii, Zaki, Aghamohammadi, \& Rocklöv, 2016; Pothitou, Varga, Kolios, \& Gu, 2017; Shaikh et al., 2017). Notably, the school are the right place to highlight the impact human make on the environment. Leaders in the schools were assuming as an agent of change and the most influential person in the institution (Robertson, 2018; Shafique \& Kalyar, 2018; Ugwu, 2018; Van Gils, Van Quaquebeke, Borkowski, \& van Knippenberg, 2018). Any policy and reformation begin from school leaders had great potential and chance to succeed. However, pro-environmental behaviour stagnant as knowledge without actual involvement among school leaders that encourage to evaluate attendance of sustainability behaviour among schools leaders (Khalid, Harun, Muda, \& Ismail, 2011). Malaysia education system limits the sustainability elements by implementing environmental education since 1998 (Khalid et al., 2011) and currently, environmental aspects are only thought and integrated as an element in every subject. Thus, school leaders need to develop and articulate clear conceptions of the vision and approach to stimulate environmental behaviour in their schools so that such implementation transform next-generation environmental behaviours.

Initially, interest toward nature, feeling of oneness with nature, love and attachment toward nature is proven to be the best predictor of nature protective behaviour. Jones (2013) try to overcome 'nature deficit disorder' in the learning institutions, and the scholar found that direct nature experiences mainly rural nature experience potentially change the level of emotion and emotional attachment to nature which lead to a high inclination to affinity toward nature. Therefore, emotional affinity toward nature has to retrieve as a direct predictor to environmental intention and behaviour. Thus, in this research emotional affinity toward nature suitable for explaining environmental responsive behaviour among school leaders. This research will be comparing the predictive power of emotional affinity toward nature (a cognitive appraisal) and school leaders' environmental responsive behaviour (a responsibility related performance appraisal)(Mulford, 2003). According to the psychological aspects, childhood nature experience is vital to preserving the environment. Schools play an essential role in eliciting environmental experience to students (Fernández, Alférez, Vidal, Fernández, \& Albareda, 2016; Krettenauer, 2017; Yost \& Ellis, 2008). Particularly, school leaders' environmental interest, feeling of oneness and love to nature may give experience through their attitude that practice environmental activities in schools (Uthamaputhran, Ahmad, Jaganathan, \& Hee, 2016.

In the education context, institutional support also plays a vital role to improve students' performance by providing administrative support, financial arrangement and opportunity that cater to their interest (Kozeracki \& Brooks, 2006). Nevertheless, school level institutional support was provided for the school management from the government to improve academic and non-academic achievement. Malaysia relies on a single entity such as the Ministry of Education to guide and collaborate with school leaders. National Institute of Education Management and Leadership or Institut Aminuddin Baki (IAB) is a leading training institute for the school leaders in Malaysia. National Professional Qualification for Educational Leaders (NPQEL) is mandatory for school leaders professional development (M. Jones et al., 2015). Six core areas covered during the training session such as "vision development; instruction and achievement; change management and innovation; resource and operation; interpersonal relationships; and self- management" (Ng, 2016). Alternatively, sustainable resource consumption may integrate with the element of the training to encourage 
environment responsive behaviours among school leaders.

\section{METHODOLOGY}

A survey method used in this study and 503 samples were used to test reliability. Data were collected by using online survey method from primary schools from Malaysia. The Likert-type scale was used to measure the items from all three variables, namely; environmental responsive behaviour, emotional affinity toward nature and institutional support.

In connection to adapt the instrument for environmental responsive behaviour, which focuses on behaviour, 12 items were adapted, which developed in the previous studies (Xiao \& Hong, 2010)(Marcinkowski, 2001). For the context of emotional affinity toward nature was assessed using a ten-item measurement adapted from (Müller, Kals, \& Pansa, 2009) and for institutional support 6 items measurement were used which adapted from past studies (Oliveira, Thomas, \& Espadanal, 2014; Zhu \& Kraemer, 2005).

\section{RESULTS}

Table 1 illustrated the reliability of all variables of the research. Usually, Cronbach's alpha used to estimate the reliability based on the inter-correlation of all the indicators in the construct. Besides, reliability is the consistency of the measures and the ranges from 0 to 1 , with a value of 0.60 to 0.70 deemed the lower limit of acceptability (Joseph F. Hair, Black, Babin, \& Anderson, 2010).

Table 1.0

Reliability Assessment for Variables

\begin{tabular}{lll}
\hline Variables & Cronbach Alpha & No. of items \\
\hline Environmental Responsive Behaviour & 0.889 & 10 \\
\hline Emotional Affinity Toward Nature & 0.969 & 10 \\
\hline Institutional Support & 0.914 & 6 \\
\hline
\end{tabular}

As shown in the findings, the Cronbach Alpha for emotional affinity toward nature indicates the highest value which is 0.969 . Reliability value for institutional support (0.914) and environmental responsive behaviour (0.889) relatively higher than minimum acceptable of reliability (Nunnally, 1978). Besides, there is no item dropped to increase the reliability of the construct. Hence, it can be concluded that the questionnaire is good and reliable for further analysis.

\section{CONCLUSION}

The main objective of this study is to assess the reliability of environmental responsive behaviour, and their influential constructs such as emotional affinity toward nature and institutional support. Result of this study indicated that all measured constructs hold good internal consistency that is consistent across the research. Therefore, these results relatively suitable and reliable in the research. Since the study on environmental behaviour related to leadership attributes are very limited, it is without a doubt that this measurements with high internal consistency could be adopted for the different context of research such as region, industry and so on. In addition, it is very crucial to include more variation in the research to establish better and consistent reliability. To sum up, it is hoped that this reviewed reliability analysis on environmental behaviour and institutional support constructs could help researchers who are interested to understand further on green behaviour adoption and institutional support.

\section{REFERENCES}

1. Abdul Rahman, H. (2014). An overview of environmental disaster in Malaysia and preparedness strategies. Iranian Journal of Public Health, 43(3), 1724.

2. Alberti, M. (2015). Eco-evolutionary dynamics in an urbanizing planet. Trends in Ecology and Evolution, pp. 114-126. https://doi.org/10.1016/j.tree.2014.11.007

3. Enger, E. D., \& Smith, B. F. (2015). Environmental Science: A Study of Interrelationship (14th ed.). New City: McGraw-Hill.

4. Fernández, M., Alférez, A., Vidal, S., Fernández, M. Y., \& Albareda, S. (2016). Methodological approaches to change consumption habits of future teachers in Barcelona, Spain: Reducing their personal Ecological Footprint. Journal of Cleaner Production, 122, 154163. https://doi.org/10.1016/j.jclepro.2016.02.026

5. Hii, Y. L., Zaki, R. A., Aghamohammadi, N., \& Rocklöv, J. (2016). Research on Climate and Dengue in Malaysia: A Systematic Review. Current Environmental Health Reports, Vol. 3, pp. 81-90. https://doi.org/10.1007/s40572-016-0078-z

6. Jones, D. R. (2013). "The biophilic university": A defamiliarizing organizational metaphor for ecological 
sustainability? Journal of Cleaner Production, 48, 148-165. https://doi.org/10.1016/j.jclepro.2013.02.019

7. Jones, M., Adams, D., Hwee Joo, M. T., Muniandy, V., Perera, C. J., \& Harris, A. (2015). Contemporary challenges and changes: principals' leadership practices in Malaysia. Asia Pacific Journal of Education, 35(3), 353-365. https://doi.org/10.1080/02188791.2015.1056591

8. Joseph F. Hair, J., Black, W. C., Babin, B. J., \& Anderson, R. E. (2010). Multivariate Data Analysis (MVDA). In British Library Cataloguing-inPublication Data (7th ed.). https://doi.org/10.1002/9781118895238.ch8

9. Kozeracki, C. a, \& Brooks, J. B. (2006). Emerging Institutional Support for Developmental Education. New Directions for Community Colleges, (136), 63-74. https://doi.org/10.1002/cc

10. Krettenauer, T. (2017). Pro-Environmental Behavior and Adolescent Moral Development. Journal of Research on Adolescence, 27(3), 581-593. https://doi.org/10.1111/jora.12300

11. Marcinkowski, T. (2001). Predictors of responsible environmental behavior: A review of three dissertation studies. Essential Readings in Environmental Education, (1973), 247-276.

12. Mohammad, N. (2011). Environmental Law and Policy Practices in Malaysia: An Empirical Study. Australian Journal of Basic and Applied Sciences, 5(9), 12481260.

13. Mulford, B. (2003). School Leaders: Challenging Roles and Impact on Teacher and School Effectiveness. Educational Management Administration \& Leadership, https://doi.org/10.1080/13603120500483672

14. Müller, M. M., Kals, E., \& Pansa, R. (2009). Adolescents' Emotional Affinity toward Nature: A Cross-Societal Study. The Journal of Developmental Processes, 4(1), 59-69.

15. Mustafa, M. (2011). The Environmental Quality Act 1974: A significant legal instrument for implementing environmental policy directives of Malaysia. IIUM Law Journal, 19(1), 34. Retrieved from http://journals.iium.edu.my/iiumlj/index.php/iiumlj/arti cle/view/1

16. Ng, A. Y. M. (2016). School leadership preparation in Malaysia: Aims, content and impact. Educational Management Administration and Leadership, 45(6), 1002-1019.

https://doi.org/10.1177/1741143216662922

17. Nor, N. M., Bahari, N. A. S., Adnan, N. A., Kamal, S. M. Q. A. S., \& Ali, I. M. (2016). The Effects of Environmental Disclosure on Financial Performance in Malaysia. Procedia Economics and Finance, 35, 117-126. https://doi.org/10.1016/S22125671(16)00016-2

18. Nunnally, J. C. (1978). Psychometric Theory (2nd ed.). Psychometric Theory.

19. Oliveira, T., Thomas, M., \& Espadanal, M. (2014). Assessing the determinants of cloud computing adoption: An analysis of the manufacturing and services sectors. Information and Management, 51(5), 497-510. https://doi.org/10.1016/j.im.2014.03.006
20. Pothitou, M., Varga, L., Kolios, A. J., \& Gu, S. (2017). Linking energy behaviour, attitude and habits with environmental predisposition and knowledge. International Journal of Sustainable Energy, 36(4), 398-414. https://doi.org/10.1080/14786451.2015.1032290

21. Robertson, J. L. (2018). The Nature, Measurement and Nomological Network of Environmentally Specific Transformational Leadership. Journal of Business Ethics, 151(4), 961-975. https://doi.org/10.1007/s10551-017-3569-4

22. Shafique, I., \& Kalyar, M. (2018). Linking Transformational Leadership, Absorptive Capacity, and Corporate Entrepreneurship. Administrative Sciences, $8(2)$, https://doi.org/10.3390/admsci8020009

23. Shaikh, P. H., Nor, N. B. M., Sahito, A. A., Nallagownden, P., Elamvazuthi, I., \& Shaikh, M. S. (2017). Building energy for sustainable development in Malaysia: A review. Renewable and Sustainable Energy Reviews, Vol. 75, pp. 1392-1403. https://doi.org/10.1016/j.rser.2016.11.128

24. Ugwu, C. I. (2018). Mediation effect of knowledge management on the relationship between transformational leadership and job performance of librarians in university libraries in Nigeria. (2014). https://doi.org/10.1177/0961000618763715

25. Uthamaputhran, L., Ahmad, F., Jaganathan, M., \& Hee, H. C. (2016). Revisiting Influence of Marketing Effectiveness and Environmental Awareness on Buying Behaviour of Green Product: a Sem Approach. Journal of Global Business and Social Entrepreneurship (GBSE).

26. Van Gils, S., Van Quaquebeke, N., Borkowski, J., \& van Knippenberg, D. (2018). Respectful leadership: Reducing performance challenges posed by leader role incongruence and gender dissimilarity. Human Relations, https://doi.org/10.1177/0018726718754992

27. Xiao, C., \& Hong, D. (2010). Gender differences in environmental behaviors in China. Population and Environment, 32(1), 88-104. https://doi.org/10.1007/s11111-010-0115-z

28. Yost, E., \& Ellis, G. D. (2008). Effect of self determination theory-based recreation activity-staging on vitality and affinity toward nature among youth in a residential treatment program. Residential Treatment for Children and Youth, 23(1-2), 5-26. https://doi.org/10.1300/J007v23n01-02

29. Zhu, K., \& Kraemer, K. L. (2005). Post-adoption variations in usage and value of e-business by organizations: Cross-country evidence from the retail industry. Information Systems Research, 16(1), 61-84. https://doi.org/10.1287/isre.1050.0045 